\title{
Annealing Ambient Influence on Holding Time Characteristics of ${ }^{75} \mathbf{A s}^{+}$-Implanted MOSFET's
}

\author{
Tsuyoshi GoTOH*, Kunio NAKAMURA*, Masao NOJIRI* \\ and Mototaka KAMOSHIDA*
}

Implantation of arsenic ions is an effective technique for formation of shallow source and drain junction in short channel MOSIC's, because of smaller diffusion coefficient than phosphorus even at high temperatures, and high controllability ${ }^{13}$. Leakage current of arsenic-implanted junction has already been measured, and it is reported that a minimum annealing temperature of $900^{\circ} \mathrm{C}$ is required to produce low-leakage junction, which is comparable to conventional phosphorus diffused junction ${ }^{2}$. Refreshtime of dynamic MOS RAM fabricated by using arsenic ion implantation has also been measured, and the mean refreshtime of $150 \mathrm{msec}$ at $75^{\circ} \mathrm{C}$ has been obtained ${ }^{3}$. These results indicate that arsenic ion implantation might be adaptable to MOSIC's fabrication. Post-implantation annealings in all the above investigations, however, were carried out in nitrogen atmosphere. It is often required that annealing is carried out in oxidizing atmosphere to grow passivating oxide layer simultaneously, to prevent short circuit or to reduce parasitic capacitance between implanted layer and metallization. However there have been few experimental data reported on junction characteristics of ${ }^{75} \mathrm{As}^{+}$-implanted layers annealed in oxidizing atmosphere. In this note, we report the results of holding time characteristics of ${ }^{\prime \prime} \mathrm{As}^{+}$-implanted MOSFET's annealed in oxidizing atmosphere, since they are very important for application to dynamic MOSRAM's.

The $n$-channel Si-gate MOSFET's were fabricated on $1.4 \Omega-\mathrm{cm}, \quad p$-type $\mathrm{Si}$ wafers. The processes were the same as those conventionally used in the fabrication of short channel Si-gate MOS transistors, except that thermal

\footnotetext{
* IC Division, Nippon Electric Co., Ltd. (1753 Shimonumabe, Nakahara-ku, Kawasaki)

Key words: Arsenic, Ion Implantation, Annealing, Holding Time
}

phosphorus diffusion into source and drain regions was replaced by arsenic ion implantation. The ${ }^{75} \mathrm{As}^{+}$ions of $5 \times 10^{15} / \mathrm{cm}^{2}$ were implanted through $400 \AA$-thick oxide with a $100 \mathrm{keV}$ accelerating energy into source and drain regions. Subsequent annealings were performed at $1000^{\circ} \mathrm{C}$ in the ambients of nitrogen, dry oxygen and steam for 30 minutes. Increase in thickness of the oxide layer after annealing was less than $500 \AA$ in the case of dry oxygen ambient. On the other hand, $0.4 \mu \mathrm{m}$-thick oxide was grown after annealing in steam. Junction depth was $0.3 \mu \mathrm{m}$ in cases of nitrogen and dry oxygen ambients, and $0.25 \mu \mathrm{m}$ in the case of steam ambient. Correspondingly, sheet resistance was $40 \Omega / \square$ in first two cases, and $45 \Omega / \square$ in the third case. For comparison, phosphorus diffused samples of $0.5 \mu \mathrm{m}$ junction depth were also fabricated.

$A$ circuit used for the measurement of holding time is shown in Fig. 1 (a). A single pulse $\phi_{\mathrm{G}}$ of $1 \mathrm{msec}, 8 \mathrm{~V}$ was applied to the transfer gate terminal, and the input pulse $V_{\text {in }}$ of 2 msec, $8 \mathrm{~V}$ was on. The holding time is defined by the time when the total stored charges are released to the surrounding area from the storage region shown by thick line in Fig. 1 (a). The stored charges may be discharged through junction leakage and gate oxide leakage. The leakage current through oxide is usually a few orders of magnitude smaller than the junction leakage current, and its effect can be neglected. The typical holding time characteristic is shown in Fig. 1 (b). The curve indicates time decay of the output voltage. The output voltage increases gradually due to release of stored charge, which is caused by recombination current of the holding junction, and then abruptly goes up to $V_{\mathrm{DD}}$ due to the increase of substrate current which flows in the sense transistor'). 


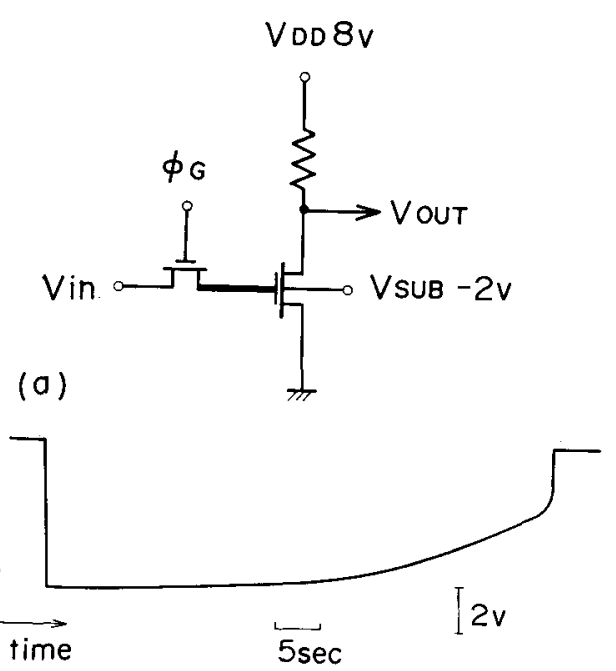

(b)

Fig. 1 Diagram of the circuit used for measurement of holding time characteristics (a), and typical example of holding time characteristics (b)

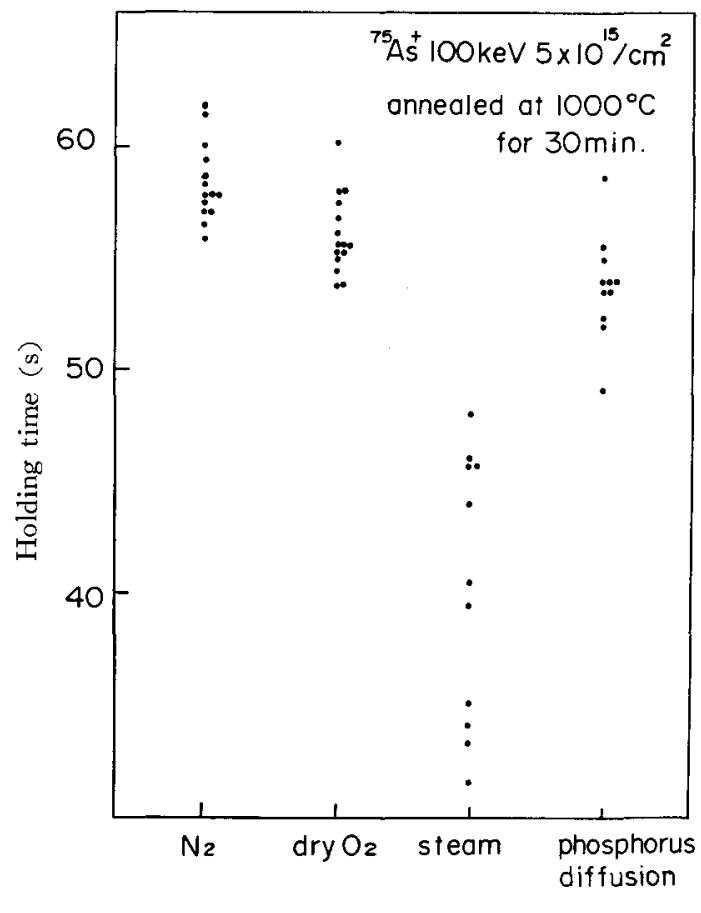

Annealing condition

Fig. 2 Holding times measured on ${ }^{75} \mathrm{As}^{+}$implanted samples annealed in various ambients. For comparison, values for phosphorus diffused samples are also shown
Holding times of samples annealed in various ambients of nitrogen, dry oxygen and steam at $1000^{\circ} \mathrm{C}$ for 30 minutes after the implantation are shown in Fig. 2. The holding times of the samples annealed in the nitrogen ambient are comparable to those for the phosphorus diffused samples. This result is consistent with the previously reported results ${ }^{2,3)}$. The amount of the charge $Q$ stored in the region indicated by thick line in Fig. 1 (a) is approximated by $Q \approx C \cdot\left(V_{\mathrm{in}}-V_{\mathrm{T}}\right)$, where $C$ is the gate oxide capacitance of the sense transistor. In the present case, the gate oxide thickness is $400 \AA$, and $C$ becomes $0.27 \mathrm{pF}$ (gate area is $320 \mu \mathrm{m}^{2}$ ). The stored charge $Q$ becomes $1.8 \times 10^{-12}$ coulomb. Hence, the average leakage current density through the holding junction $\left(\mathrm{I}_{\text {leak }} \approx\right.$ $Q / \tau$ ) is about $7 \times 10^{-16} \mathrm{~A} / \mu \mathrm{m}^{2}$ (junction area is $\left.45 \mu \mathrm{m}^{2}\right)$. This value is low enough, and comparable to that of conventional phosphorus diffused junction. The holding times of samples annealed in steam are the shortest. This can be considered due to the fact that dislocation loops or dislocation networks are generated during the anneal, and possible metal impurities, which become recombination centers, precipitate into these loops or networks, as revealed by TEM observation by Akasaka and Tsukamotos). In the present measurement, the holding times of samples, annealed in dry oxygen ambient, are comparable to those for phosphorus diffused samples. We consider that the number of dislocation loop or dislocation network is not enough to degrade the junction characteristics after annealed in dry oxygen, when the implantation is performed through $\mathrm{SiO}_{2}$ layers. Tsukamoto et al. also reported that junction breakdown characteristics are not so much degraded in the case of dry oxygen ambient as in the case of steam ambient ${ }^{6}$.

In conclusion, the holding time characteristics of ${ }^{75} \mathrm{As}^{+}$-implanted MOSFET's have been measured. Holding times of the samples annealed in ambients of nitrogen and dry oxygen at $1000^{\circ} \mathrm{C}$ for 30 minutes are comparable to those for phosphorus diffused samples. It has been found that annealing in steam ambient considerably degrades holding time characteristics.

The authors with to thank Drs. S. Nakanuma, T. Okada, and T. Wada for their encouragement. The 
help by $\mathrm{O}$. Kudoh and $\mathrm{M}$. Tsurumi in holding time measurements was invaluable.

$<$ E565 $>$ (Received Dec. 2, 1978)

\section{References :}

1) K. Nakamura and M. Kamoshida, J. Electrochem. Soc. 125, 1518 (1978).

2) A. E. Michel, F. F. Fang and E. S. Pan, J. Appl. Phys. 45, 2991 (1974).

3) Y. Wada, S. Nishimatsu and K. Sato, Solid-State
Electron. 21, 513 (1978).

4) O. Kudoh, H. Yamanaka, M. Tsurumi and T. Wada, IEEE J. Solid-State Circuit. SC-13, 235 (1978).

5) Y. Akasaka and K. Tsukamoto, Oyo Buturi 46, 1131 (1977).

6) K. Tsukamoto, Y. Akasaka, Y. Watari, Y. Kusano, Y. Hirose and G. Nakamura, Japan. J. Appl. Phys. 17, Suppl. 17-1, 187 (1978).

\section{$\succeq$ 協 会}

\section{第 2 回工業電解用電極材料技術懇談会}

上記第2 回の研究会が 5 月 10 日（木）午後横浜国立 大学エネルギー材料研究施設で開かれた. 約 40 名の方 タが参会された。

当日のプログラムの最初は，金属材料技術研究所の藤 井哲雄, 小玉俊明両氏の研究で,「プラズマジェット溶 射法被覆チタン電極の開発について」であった，小玉氏 が講演された。

ニッケルフェライト，コバルトフェライト，マグネタ イト，古成したのち，プラズマ溶射でチタン基板の上 に吹付け，フェライトのもつ電極触媒能と金属チタンの 電極基板としての特性と索組合せた複合材料電極索作成 することが狙いである。

食塩水を電解したときのアノードガスの分析結果, フ ェライトの溶解性試験, 分極特性, などの結果をもとに 活発な討諭が行なわれた. ウスタイトの生成などを含め た溶射時の熱分解, フェライトの溶解損耗および優先溶 解の有無, 基板チタンの不動態化に伴う活性低下などが 話題となった.

次に中川防蝕工業（株）の福谷英二氏から「電気防食
用難溶性電極の現状と将来」について防食技術 $[27$, 583 (1978)] に発表された解説资料として紹介があっ た. 黒鉛系電極注わが国ではあまり用いられていないが 海水中の使用には最適である．高方素鋳鉄系電極は土 中，淡水中の使用に適している．磁性酸化鉄電極は主と して土中電䄈として用いら机る。フェライト系電極は小 型施設の電気防食が対象となる. 鉛系電極は壏素イオン のある環境で，抵抗率の低い場合に消耗量が少なく，海 水中の電極として圧倒的に多く使用される．白金系電極 はほとんどすべての環境で使用呵能である. $\mathrm{RuO}_{2}$ 被覆 の DSA 怕金系電極の代用として今後用途が増加する であろう。

討論では福谷氏の長年にわたる使用経験にもとついた 含蓄のある話を伺うことができたたたえば電極系全体 としての寿命を支配するのは電極本体の寿命ではなく， 結線部の断線事故である場合が多い.

討諭のあとは高橋䈍談会主查を囲んでの懇親会が開か れ参加者の意見の交流を一層深いものとした・第 3 回の 会合は7月 26 日 (木) 午後同しく横浜国立大学エネル ギー材料施設 (弘明寺) で開かれる（電気化学 4 月号 p. 297 会告参照).

（東京大学生産技術研究所 増子 昇） 